\title{
Water Imbibition Capacity of Some Nigerian Timbers: A Function of Wood Density and Structure
}

\author{
Okoye, N. H. ${ }^{1 *}$, Eboatu A.N. ${ }^{1}$, Arinze, R.U. ${ }^{1}$, Umedum, N. L. ${ }^{1}$, Udeozo P.I. ${ }^{2}$ and \\ Ogbonna, O.A. ${ }^{3}$ \\ 1 Dept. of Pure \& Industrial Chemistry, Nnamdi Azikiwe University, Awka, Anambra State. \\ 2 Dept. of Chemical Sciences, Tansian University, Oba, Anambra State, Nigeria. \\ 3 Dept. of Science Laboratory Technology, Institute of Management and Technology, Enugu, Enugu State.
}

\begin{abstract}
Wood is a heterogeneous, hygroscopic, cellular and anisotropic material of biological origin. The properties of wood that make it an ideal raw material for several purposes are mainly determined by the specific architecture of the cell walls. Moisture content, porosity and water imbitition capacity contribute to the quality of timber. The examination of the internal microscopic structure of the timber samples will be done by Scanning Electron Microscopy (SEM). Of the fifty-three timbers studied, thirty-two were of medium density $\left(0.403 \pm 0.020\right.$ to $\left.0.715 \pm 0.011 \mathrm{~g} / \mathrm{cm}^{3}\right)$, ten were of low density $\left(0.256 \pm 0.008\right.$ to $\left.0.380 \pm 0.012 \mathrm{~g} / \mathrm{cm}^{3}\right)$ and eleven were quite dense $\left(0.784 \pm 0.020\right.$ to $\left.1.111 \pm 0.039 \mathrm{~g} / \mathrm{cm}^{3}\right)$, with Ricinodendrom heudelotti having the least value and Irvinga smithii, the highest. Water imbibitions capacity after 24 hours was quite high for Ricinodendrom heudelotti and Ceiba pentandra while that for Irvinga smithii, Lophira lanceolate, Khaya senegalensis and Erythrophleum suaveolens were low. There was an inverse relationship between the maximum moisture content of these wood samples and their density. The scanning electron micrographs of selected timbers present ring- porous hardwoods as well as diffuse- poruos hardwoods.Fibrous nature of Entradrophragma utile and Hollarhena floribunda may account for their high moisture content (MC) values while the spherical granules in Tetrapluera tetraptera are suspected to be hydrophobic since the water imbibition capacity observed after $24 \mathrm{~h}$ was lower than those of similar density.
\end{abstract}

Keywords: Wood density, water imbibition capacity, porosity index, moisture content, $\quad$ Scanning Electron Microscopy.

\section{Introduction}

Wood is a very important raw material; not only is it used for literally hundreds of products but also it is a renewable natural resource. It is a hard fibrous tissue found in many plants. Wood is a heterogeneous, hygroscopic, cellular and anisotropic material of biological origin. Wood (or xylem in a more strict sense) conducts water and mineral salts from root to the leaf and gives mechanical strength to the plant body. It is composed of cells and the cell walls are made up of microfibrils of cellulose (40-50\%) and hemicelluloses (15$35 \%$ ) impregnated with lignin (15-25\%) and extractives [Rowell et al, 2005]. The properties of wood that make it an ideal raw material for several purposes are mainly determined by the specific architecture of the cell walls. These properties include moisture content, density, mechanical, thermal, electrical, decay and chemical resistance properties. Moisture content, susceptibility to insect attacks, workability, grains, colour, porosity and capacity to take polish and varnish contribute to the quality of timber [Dutta, 1995]. The examination of the internal microscopic structure of the timber samples was done by Scanning Electron Microscopy(SEM). These timbers were classified with respect to their density and porosity indices which give a guide to their permeability and strength properties.

\section{Moisture Content}

Due to the need for water as part of the photosynthesis and growth process, wood in growing trees contains a considerable amount of water, commonly called sap. The water in wood is either held within cell walls by bonding forces (hydrogen bonding) between water and cellulose molecules or contained in the cell cavities and not held by these forces. In the first case, it is referred to as bound water and in the latter case, as free water. The amount of water in wood, called the moisture content, is expressed as a percentage of the dry weight and is dependent on the relative humidity and temperature of the surrounding air. The ability of wood to lose or gain water content affects its structural properties such as weight, dimensions and strength characteristics [http://www.cof.orst.ed/cof/teach/for111/Brownlectures/Basic wood properties.pdf].

\section{Density and Specific Gravity}

Density is a substance's mass per unit volume. Wood density varies with moisture content which affects both mass and volume. The density of the substance that makes up a wood cell wall has been found to 
be about $1.5 \mathrm{~g} / \mathrm{cm}^{3}$, but that of an actual wood sample is usually less than $0.9 \mathrm{~g} / \mathrm{cm}^{3}$ since it contains air in the cell lumens [NAFI, 2004]. Wood density is classified by the International Association of Wood Anatomists (IAWA) in the following manner: low, $\leq 0.400 \mathrm{~g} / \mathrm{cm}^{3}$, medium, $0.400-0.750 \mathrm{~g} / \mathrm{cm}^{3}$ and high, $\geq 0.750 \mathrm{~g} / \mathrm{cm}^{3}$ [Reyes, 1992]. Specific gravity (SG) is the density of a substance relative to the density of water and is sometimes known as 'relative density or basic density'. The specific gravity of wood is influenced by moisture content, proportion of wood volume made of various kinds of cell types and cell wall thickness and size of cells and cell lumens[Wiedenhoeft, 2010]. Maximum moisture content, $\mathbf{M}_{\max }$, for any specific gravity can be calculated from: $\quad \mathrm{M}_{\max }=100\left(1.54-\mathrm{G}_{\mathrm{b}}\right) / 1.54 \mathrm{G}_{\mathrm{b}}$

where $G_{b}$ is basic specific gravity (based on oven dry weight and green volume) and 1.54 is specific gravity of wood cell walls [Winnandy, 1994; Encyclopedia of Wood by USDA].

\section{Scanning Electron Microscopy (SEM)}

Scanning electron microscopy is a type of microscopy that images a sample by scanning it with a highenergy beam of electrons in a rather faster scan pattern. The electrons interact with the atoms that make up the sample producing signals that contain information about the sample surface topography, composition and other properties. This technology has changed the ways of investigating materials by allowing researchers to image and obtain non-destructive analyses of micron-sized samples. The SEM is a microscope that uses electrons rather than light to form an image [http://www.mos.org/s/n/SEM]. This technique has many advantages which include, having a large depth of field, producing images of high resolution and easy preparation of samples. This condition is achieved for wood by coating the samples with carbon followed by gold-palladium. [McMillin, 1977].

\section{Samples collection}

\section{Experimentals}

Tropical timbers were sourced from the Rain Forest and Guinea Savanna regions of Nigeria, particularly from Enugu, Kogi, Anambra and Edo States.

Density Measurements.

Each of the timber species was cut into cubes of sides $25 \mathrm{~cm}$. Five cubes were randomly selected from each of the timber species. The weights $\left(\mathrm{W}_{1}\right)$ of the freshly cut cubes were taken and the volume $\left(\mathrm{V}_{1}\right)$ calculated by measuring the length, breadth and height of the cubes. The wet density $\mathrm{D}_{\mathrm{w}}$ was then calculated using the formula: $\quad \mathrm{D}_{\mathrm{w}}=\mathrm{W}_{1}\left(\mathrm{~g} / \mathrm{cm}^{3}\right)$

$\mathrm{V}_{1}$

For oven-dry density (ODD) measurement, these cubes were dried in an oven at $105^{\circ} \mathrm{C}$ for 48 hours and the weight $\left(\mathrm{W}_{2}\right)$ and volume $\left(\mathrm{V}_{2}\right)$ of the oven-dried cubes was used for the calculation. Each experiment was repeated five times and the results averaged.

\section{Measurement of Water Imbibitition Capacity}

This was determined using the modified ASTM D-1037 method by immersing five cubes of each of the timber species in water for $1 \mathrm{~h}$ and $24 \mathrm{~h}$ and weighing the wet cubes $\left(\mathrm{W}_{3}\right)$, one at a time, after the respective stipulated times. Water imbitition capacity $=\underline{\mathrm{W}}_{\underline{3}}-\mathrm{W}_{2} \times 100(\%)$

Five readings were made for each timber species and the average taken.

Scanning Electron Microscopy (SEM)

Using the and Scanning Electron microscope (SEM) Model EVO MA 10 at SHESTCO, Abuja, the cellular structure/ morphology of the wood samples was obtained.

\section{Results And Discussions}

The results of the ovendry density measurements of the timbers (Table 1) indicate that the density values of the timbers were in the range of $0.256 \pm 0.008 \mathrm{~g} / \mathrm{cm}^{3}$ to $1.111 \pm 0.039 \mathrm{~g} / \mathrm{cm}^{3}$, with Ricinodendrom heudelotti having the least value and Irvinga smithii, the highest. Of the fifty-three timbers,arranged in increasing order of denisty, thirty-two were of medium density $\left(0.403 \pm 0.020\right.$ to $\left.0.715 \pm 0.011 \mathrm{~g} / \mathrm{cm}^{3}\right)$, ten were of low density $\left(0.256 \pm 0.008\right.$ to $\left.0.380 \pm 0.012 \mathrm{~g} / \mathrm{cm}^{3}\right)$ and eleven were quite dense $(0.784 \pm 0.020$ to 1.111 $\left.\pm 0.039 \mathrm{~g} / \mathrm{cm}^{3}\right)$. This concurs with the observation made by Reyes et al [1992] that the most frequent wood densities in tropical American, Asian and Africa timber species compiled were 0.5 to $0.8 \mathrm{~g} / \mathrm{cm}^{3}$. The values for the corresponding wet densities followed nearly the same trend but were noticably different for Buchozia curiacea and Cassia nodosa which have very high and low wet densities, respectively, when compared to their ODDs. 
Water Imbibition Capacity of Some Nigerian Timbers: A Function of Wood Density and Structure

\section{Moisture Content}

It is observed that the moisture content of the timbers were relatively the same, with an average value of $14.819 \pm 3.710 \%$ (Table 1). Timbers such as Cassia nodosa (6.019\%), Anacardium occidentalis (7.848\%), and Erythrophilum suaveolens (8.230\%) had MC values much lower than air dry wood while those for Entandrophragma utile (22.83\%), Hollarrhena floribunda (24.25\%) and Buchozia curiacea (31.95\%) were much higher. This condition may be attributed to the chemical composition of the individual wood and the void volume in the wood [Siau, 1971].

Table 1: Results of water imbibition capacity of the various timbers after $1 \mathrm{~h}$ and $24 \mathrm{~h}$.

\begin{tabular}{|c|c|c|c|c|c|c|c|}
\hline Botanic name & $\begin{array}{l}\text { Oven dry } \\
\text { Density }(\mathrm{g} / \mathrm{cm} 3)\end{array}$ & $\begin{array}{l}\text { Class of } \\
\text { density }\end{array}$ & $\begin{array}{l}\text { Specific } \\
\text { Gravity, } \\
\mathrm{Gb}^{*}\end{array}$ & $\begin{array}{l}\text { Actual } \\
\text { MC }(\%)\end{array}$ & $\begin{array}{l}\text { Moisture } \\
\text { after } 1 \mathrm{~h}, \%\end{array}$ & $\begin{array}{l}\text { Moisture } \\
\text { after } 24 \mathrm{~h}, \%\end{array}$ & $\begin{array}{l}\text { Maximum } \\
\text { MC, \% } \\
\text { (Calculated) }\end{array}$ \\
\hline $\begin{array}{l}\text { Ricinodendrom } \\
\text { heudelotti }\end{array}$ & $0.256 \pm 0.008$ & Low & 0.226 & 13.292 & 89.4 & 226.3 & 378.4 \\
\hline Ceiba petandra & $0.281 \pm 0.019$ & Low & 0.241 & 16.881 & 62.7 & 182.2 & 350.8 \\
\hline Xylopia aethiopica & $0.283 \quad 0.032$ & Low & 0.251 & 13.009 & 65.8 & 109.4 & 334.1 \\
\hline Hollarrhena floribunda & $0.308 \pm 0.020$ & Low & 0.248 & 24.251 & 44.6 & 117.5 & 337.9 \\
\hline Cassia nodosa & $0.311 \pm 0.021$ & Low & 0.294 & 6.019 & 39.4 & 109.1 & 275.7 \\
\hline Daniella ogea & $0.344 \pm 0.048$ & Low & 0.298 & 15.354 & 32.3 & 91.5 & 270.3 \\
\hline Spondias mombium & $0.350 \pm 0.025$ & Low & 0.307 & 13.901 & 45.1 & 101.7 & 260.5 \\
\hline $\begin{array}{l}\text { Triplochyton } \\
\text { scleroxylon }\end{array}$ & $0.380 \pm 0.007$ & Low & 0.329 & 15.528 & 33.2 & 87.6 & 239.1 \\
\hline $\begin{array}{l}\text { Distemonthus } \\
\text { benthamiamus }\end{array}$ & $0.380 \pm 0.012$ & Low & 0.330 & 15.188 & 38.3 & 107.1 & 237.8 \\
\hline Hannoa klaineana & $0.403 \pm 0.020$ & Low & 0.355 & 13.628 & 36.4 & 93.8 & 216.7 \\
\hline $\begin{array}{l}\text { Anacardium } \\
\text { occidentalis }\end{array}$ & $0.443 \pm 0.043$ & Medium & 0.411 & 7.848 & 65.1 & 104.3 & 178.3 \\
\hline Tetrapleura tetraptera & $0.467 \pm 0.018$ & Medium & 0.406 & 15.086 & 20.9 & 58.8 & 181.3 \\
\hline Pterocarpus soyauxi & $0.470 \pm 0.014$ & Medium & 0.412 & 13.982 & 27.5 & 80.1 & 177.8 \\
\hline $\begin{array}{l}\text { Anthocleista } \\
\text { djalonensis }\end{array}$ & $0.470 \pm 0.073$ & Medium & 0.407 & 15.705 & 20.8 & 69.4 & 181.0 \\
\hline Terminalia superb & $0.478 \pm 0.024$ & Medium & 0.421 & 13.506 & 20.0 & 73.3 & 172.6 \\
\hline Buchozia curiacea & $0.503 \pm 0.021$ & Medium & 0.381 & 31.954 & 20.5 & 71.7 & 197.3 \\
\hline Diospros dendo & $0.504 \pm 0.027$ & Medium & 0.429 & 17.578 & 23.2 & 57.6 & 168.1 \\
\hline Crescentia cujete & $0.520 \pm 0.019$ & Medium & 0.451 & 15.425 & 18.0 & 64.5 & 156.9 \\
\hline $\begin{array}{l}\text { Harungana } \\
\text { madagasceriensis }\end{array}$ & $0.532 \pm 0.066$ & Medium & 0.471 & 12.949 & 19.3 & 49.5 & 147.5 \\
\hline Morinda lucida & $0.535 \pm 0.005$ & Medium & 0.458 & 16.895 & 21.1 & 64.5 & 153.6 \\
\hline Prosopis Africana & $0.547 \pm 0.027$ & Medium & 0.483 & 13.422 & 26.3 & 74.9 & 142.3 \\
\hline Vitex doniana & $0.554 \pm 0.031$ & Medium & 0.489 & 13.235 & 24.3 & 88.1 & 139.6 \\
\hline Alchornea cordifolia & $0.564 \pm 0.048$ & Medium & 0.508 & 11.092 & 41.8 & 90.0 & 132.1 \\
\hline Terminalia ivorensis & $0.571 \pm 0.036$ & Medium & 0.507 & 12.657 & 10.9 & 44.4 & 132.2 \\
\hline Celtic zenkeri & $0.592 \pm 0.024$ & Medium & 0.508 & 16.464 & 42.3 & 100.0 & 131.8 \\
\hline Daniella oliveri & $0.598 \pm 0.014$ & Medium & 0.530 & 12.957 & 26.7 & 71.7 & 123.8 \\
\hline Cola hipsida & $0.611 \pm 0.098$ & Medium & 0.541 & 12.952 & 16.1 & 58.0 & 120.0 \\
\hline Manilkara obovata & $0.623 \pm 0.031$ & Medium & 0.531 & 17.333 & 16.9 & 54.3 & 123.3 \\
\hline Cassia sieberiana & $0.625 \pm 0.017$ & Medium & 0.531 & 17.743 & 17.2 & 60.5 & 123.4 \\
\hline Entandrophragma utile & $0.625 \pm 0.110$ & Medium & 0.509 & 22.830 & 42.9 & 84.7 & 131.5 \\
\hline Nauclea latifolia & $0.627 \pm 0.028$ & Medium & 0.543 & 15.525 & 23.6 & 56.3 & 119.3 \\
\hline Parkia biglobosa & $0.629 \pm 0.013$ & Medium & 0.543 & 15.795 & 20.8 & 64.8 & 119.1 \\
\hline Detarium microcarpum & $0.629 \pm 0.037$ & Medium & 0.543 & 15.919 & 17.0 & 60.1 & 119.3 \\
\hline Tecoma stans & $0.641 \pm 0.146$ & Medium & 0.549 & 16.702 & 34.9 & 90.9 & 117.1 \\
\hline Pentadesma butyracea & $0.642 \pm 0.032$ & Medium & 0.563 & 14.089 & 20.2 & 58.1 & 112.6 \\
\hline Albizie adianthifolia & $0.649 \pm 0.040$ & Medium & 0.568 & 14.271 & 20.6 & 66.8 & 111.0 \\
\hline Ficus platyphylla & $0.664 \pm 0.015$ & Medium & 0.579 & 14.824 & 16.5 & 56.3 & 107.9 \\
\hline Topinanthus globiferus & $0.668 \pm 0.064$ & Medium & 0.579 & 15.498 & 13.7 & 43.8 & 107.9 \\
\hline Parkia bicolor & $0.670 \pm 0.024$ & Medium & 0.590 & 13.634 & 26.5 & 63.6 & 104.6 \\
\hline Albizie ferruginea & $0.687 \pm 0.026$ & Medium & 0.598 & 14.817 & 8.7 & 30.5 & 102.3 \\
\hline Myrianthus aboreus & $0.706 \pm 0.076$ & Medium & 0.619 & 13.953 & 21.9 & 58.3 & 96.5 \\
\hline Afzelia Africana & $0.715 \pm 0.011$ & Medium & 0.637 & 12.159 & 8.5 & 29.0 & 92.0 \\
\hline $\begin{array}{l}\text { Penthacletha } \\
\text { macrophylla }\end{array}$ & $0.784 \pm 0.020$ & High & 0.683 & 14.784 & 11.8 & 46.9 & 81.6 \\
\hline Eucalyptus globules & $0.786 \pm 0.021$ & High & 0.682 & 15.336 & 22.8 & 60.6 & 81.7 \\
\hline $\begin{array}{l}\text { Spathodea } \\
\text { campanulata }\end{array}$ & $0.786 \pm 0.101$ & High & 0.669 & 17.611 & 14.1 & 48.7 & 84.6 \\
\hline Brastegia eurycoma & $0.794 \pm 0.051$ & High & 0.698 & 13.791 & 7.2 & 31.8 & 78.4 \\
\hline Pycnanthus angolensis & $0.864 \pm 0.038$ & High & 0.777 & 11.263 & 9.9 & 33.5 & 63.8 \\
\hline Nauclea diderichii & $0.896 \pm 0.074$ & High & 0.785 & 14.208 & 9.7 & 36.2 & 62.5 \\
\hline Lophira lanceolate & $0.897 \pm 0.018$ & High & 0.778 & 15.260 & 4.7 & 18.9 & 63.5 \\
\hline
\end{tabular}


Water Imbibition Capacity of Some Nigerian Timbers: A Function of Wood Density and Structure

\begin{tabular}{|l|l|l|l|l|l|l|l|}
\hline $\begin{array}{l}\text { Piptadeniastrum } \\
\text { africanum }\end{array}$ & $0.963 \pm 0.069$ & High & 0.856 & 12.575 & 7.0 & 25.1 & 51.9 \\
\hline $\begin{array}{l}\text { Erythrophleum } \\
\text { suaveolens }\end{array}$ & $1.069 \pm 0.041$ & High & 0.988 & 8.230 & -0.2 & 11.2 & 36.3 \\
\hline Khaya senegalensis & $1.106 \pm 0.036$ & High & 0.971 & 13.874 & 3.2 & 16.5 & 38.0 \\
\hline Irvingia smithi & $1.111 \pm 0.039$ & High & 0.975 & 13.964 & 13.2 & 30.6 & 37.7 \\
\hline
\end{tabular}

\section{Water imbibition capacity}

Fig. 1 shows that after 24 hours of immersion in water the timber samples had not imbibed their maximum capacity and that the \% difference reduced as the density of the timbers increased (59.9 to 30.7\%). The maximum moisture content of wood is reached when the cell walls and cell lumens are completely filled with water. When specific gravity is high, lumen volume is low and maximum MC is therefore restricted [Simpson, 1993]. Water imbibitions capacity after 24 hours was quite high for Ricinodendrom heudelotti and Ceiba pentandra when compared to their corresponding values after 1 hour immersion; while that for Irvinga smithii, Lophira lanceolate, Khaya senegalensis and Erythrophleum suaveolens were low..

Fig. 1: Plot of moisture absorbed vs. oven-dry density of timber species.

\section{Scanning Electron Microscopy}

The scanning electron micrographs of selected timbers, in ascending order of density, are presented in Figs. 2-9; present ring- porous hardwoods as well as diffuse- porous hardwoods. The moisture content of these wood whose micrographs are shown in these figures have been shown to fall within the range 7.848 to $24.25 \%$ with the least being Anacardium occidentalis (Fig. 5), and the highest Hollarhena floribunda (Fig.3). However, most of the values were within the mean value of $152 \%$. A closer look at the micrographs of Entradrophragma utile (Fig.9) and Hollarhena floribunda shows some similarities in the fibrous nature which may account for their high moisture content (MC) values of $22.83 \%$ and $24.25 \%$, respectively. Fibrous tissues may retain more water in the cell walls. The rather low MC value for Anacardium occidentalis cannot be readily explained, except that the non-porous or compact nature of the sample was evident despite its medium density. The spherical granules observed in Tetrapluera tetraptera (Figs. 6), having a density of $0.467 \mathrm{~g} / \mathrm{cm}^{3}$ are suspected to be hydrophobic since the water imbibition capacity observed after $24 \mathrm{~h}$ was lower than those of similar density.

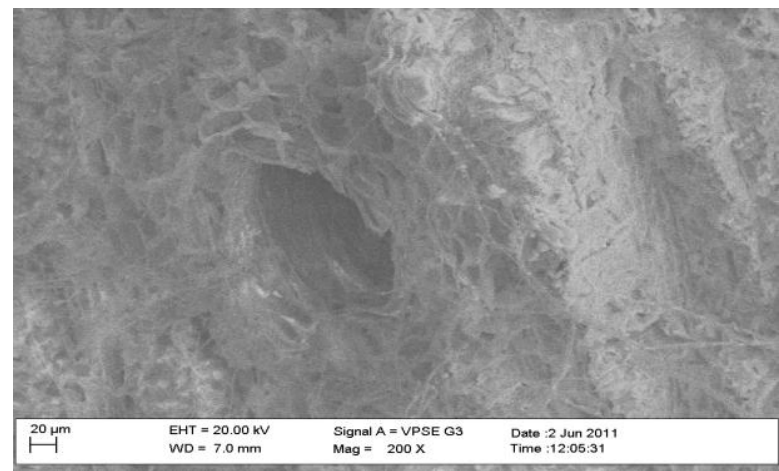

Fig.2: Scanning Electron micrograph of Ricinodendrom heudelotti

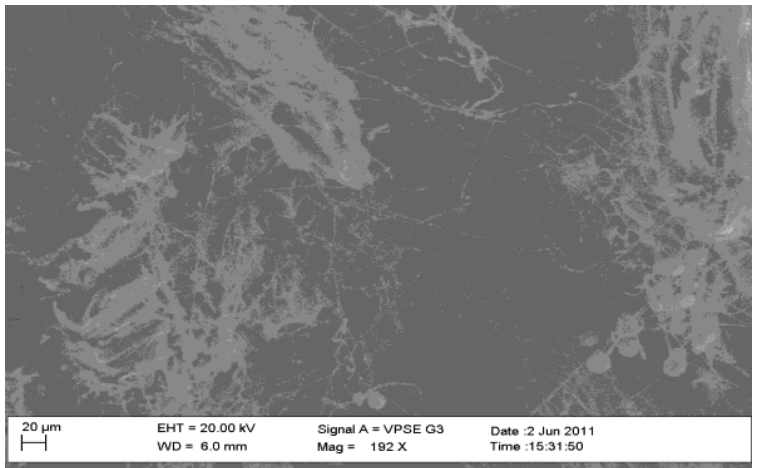

Fig.3: Scanning Electron micrograph of Hollarrhena floribunda 


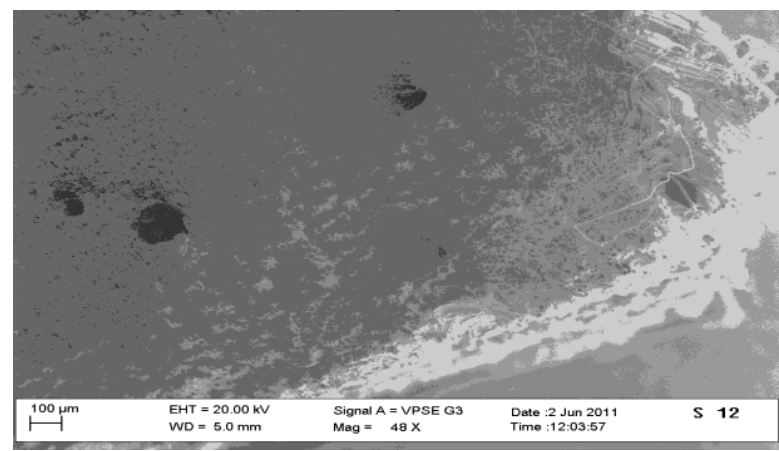

Fig.4: Scanning Electron micrograph of Triplochyton scleroxylon, $(\mathrm{Mag}=48 \mathrm{X})$

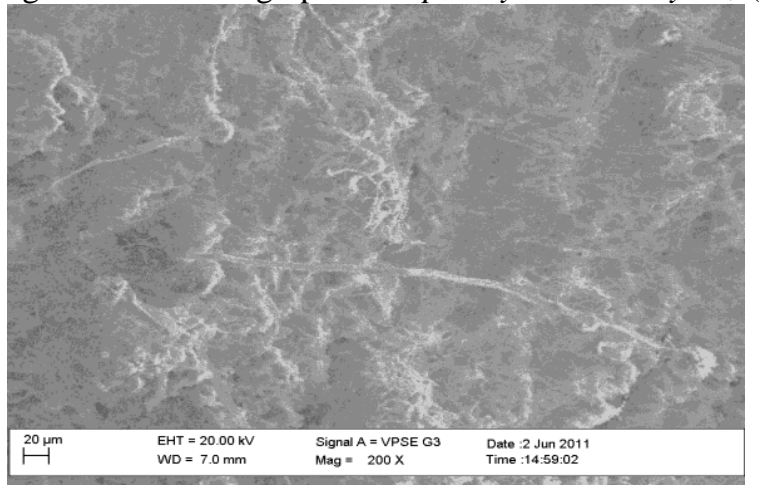

Fig.5: Scanning Electron micrograph of Anacardium occidentalis

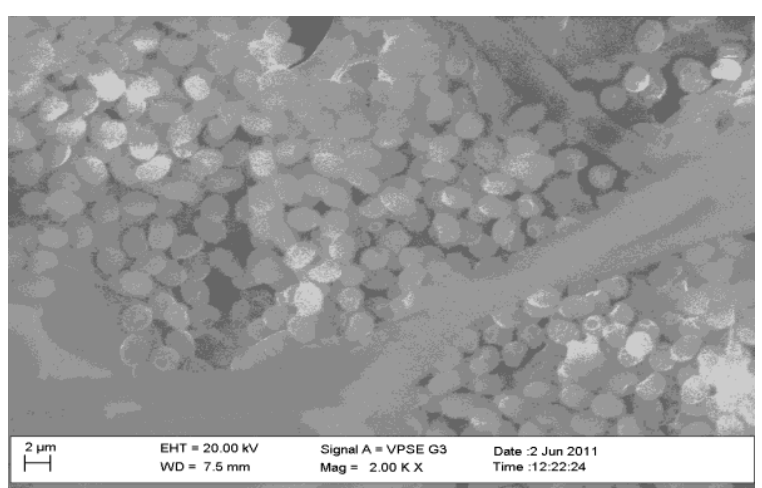

Fig.6: Scanning Electron micrograph of Tetrapleura tetraptera (2000X)

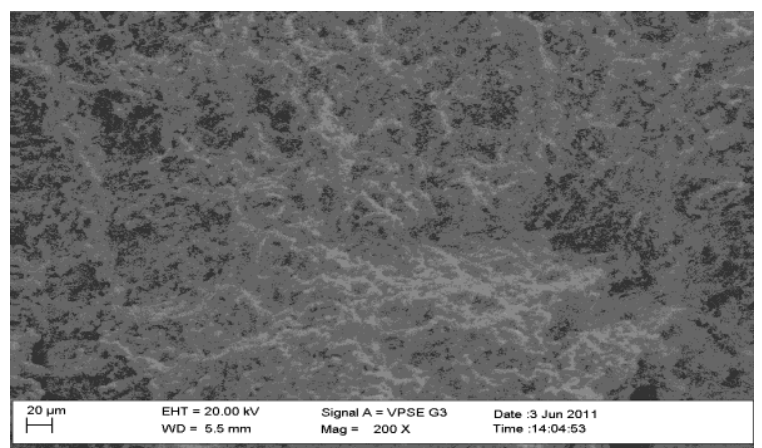

Fig.7: Scanning Electron micrograph of Terminalia superba 


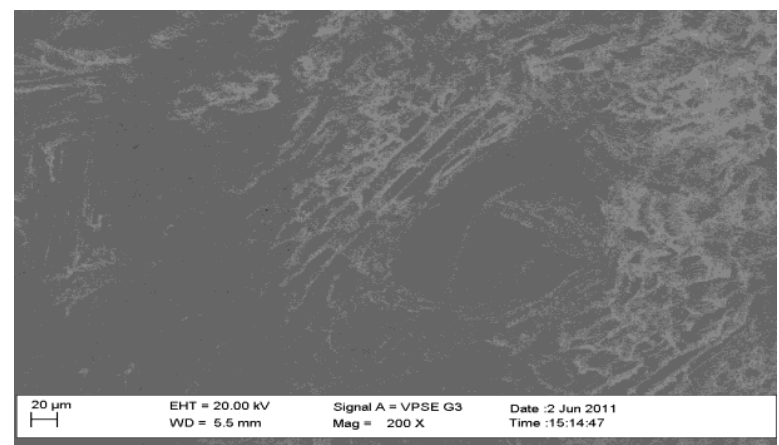

Fig.8: Scanning Electron micrograph of Diospros dendo

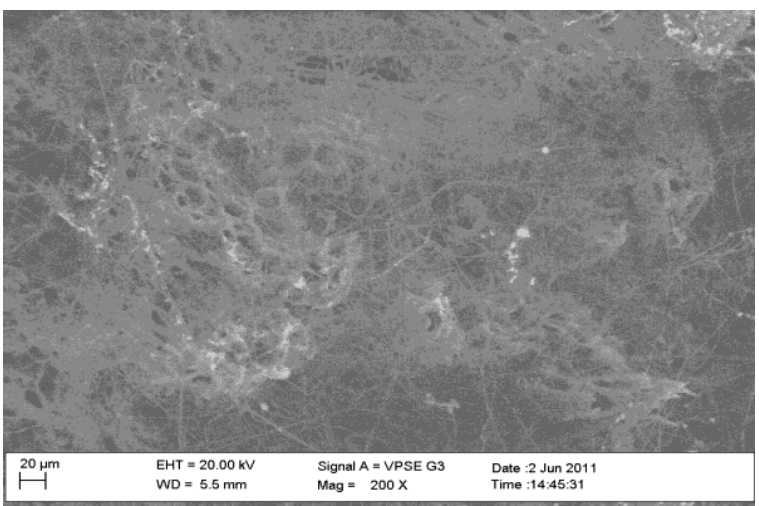

Fig.9: Scanning Electron micrograph of Entandrophragma utile

\section{Conclusions}

This study investigated the density and water imbitition capacity of fifty-three Nigerian timbers and the scanning electron microscopy of selected timber species. The following conclusions could be drawn:

Most of the timbers are of medium density; Ricinodendrom huedelotti is the least dense $\left(0.256 \pm 0.008 \mathrm{~g} / \mathrm{cm}^{3}\right)$ while Irvinga smithii is the most dense $\left(1.111 \pm 0.039 \mathrm{~g} / \mathrm{cm}^{3}\right)$.

- There was an inverse relationship between the maximum moisture content of these samples and their density.

- The scanning electron micrographs of selected timbers present ring- porous hardwoods as well as diffuse- poruos hardwoods.

The recommended practice is that the quality needed for a particular function can be specified and timbers can then be selected from the orderly graded system developed to serve the interests of the users and the producers to avoid more cost and waste.

\section{References}

[1] Dutta A.C. (1995). Botany for Degree students, $6^{\text {th }}$ ed., Oxford University Press, Calcutta, pp. 162-164, 195-202, 644.

[2] McMillin, C.W. (1977). SEM Technique for Displaying the Three- Dimensional Structure of Wood. Wood Science, 9(4), 201-204

[3] Modified ASTM Standards, D1037 (1989) - Standard Methods of Evaluating the Properties of Base Fiber and Particle Panel Materials, Part A, Sec.100 -107: Water Absorption and Thickness Swelling, pp. $167 \quad-196$. http://forest.mtu.edu/research/woodprotection/research/physical.html

[4] Moisture content in the Encyclopedia of Wood by US Department of Agriculture.

[5] http://books.google.com.ng/books?id=MUGSaitsBAIC\&pg=SA12-SAT....=moisture+content+f wood \& hl accessed on 30/09/2010.

[6] Reyes, G.; Brown, S.; Chapman, J. and Lugo, A.E. (1992): Wood Densities of Tropical Tree Species. Gen. Tech. Rep. SO-88, New Orleans, LA: U.S. Department of Agriculture, Forest Service, Southern Forest Experiment Station. 15p.

[7] Scanning Electron Microscopy. http://www.mos.org/s/n/SEM accessed on 20-10-2010

[8] Simpson, W.T.(1993). Specific Gravity, Moisture Content and Density Relationship for Wood. General Technical Report.FPLGTR-76. Madison, WI. U.S. Department of Agriculture, Forest Service, Forest Products Laboratory, 13p. http://www.fs.fed.us/ccrc/topics/urban-forests/docs/SG,MC and density relationship for wood.pdf accessed on 12/9/2010.

[9] Timber Species and Properties (2004). NAFI Timber Manual Datafile PI Revised edition, National Association of Forest Industries.

[10] Usta, I. (2003). Comparative Study of Wood Density by Specific Amount of Void Volume (Porosity). Turkish Journal of Agriculture and Forestry, 27, 1-6. http://journals.tubitak. gov.tr/agriculture/issues/tar-03-27-1/tar.27-1-1-0208-5.pdf accessed on $12 / 9 / 2010$.

[11] Wiedenhoeft, A. (2010). Wood Function and Structure. In: Forest Products Laboratory. Wood Handbook, Chapter 3. Gen. Tech. Rep. FPL-GTR-190.

[12] Winandy, J. E. (1994). Wood properties, In: Arntzen, C. J. ed. Encyclopedia of Agricultural Science, Academic Press, Orlando, 4,549-561. http://www.fpl.fs.fed.us/documents/pdf1994/winan94a.pdf. accessed on 12/04/2010. 